\title{
Ethical Customer Value Creation: Drivers and Barriers
}

\section{Grace Tyng-Ruu Lin Jerry Lin}

ABSTRACT. There is a long-standing discussion on the positive interactions between enterprise value creation and business competitiveness. The corporate value can be seen as being created from three major sources within the cycle - from employees, from processes, and from customers or investors through reinvestment. To achieve competitive advantages, a firm must create more value than its competitors in the industry. Emphasizing that, firms should explore the positive drivers of customer value creation, allowing for a true value creation that will lead to increments in competitiveness. In reality, however, there are also barriers that hinder customer value creation. Targeting the above issues that have not yet been explored or analyzed, we have collected related literature at the first stage. Based on these presumable assumptions, this paper then conducts an empirical study by surveying and analyzing the relevance given by the investigated leading machinery measuring equipment firms in Taiwan, regarding the concerns as drivers and barriers in relation to customer value creation. This paper especially aims to answer several key questions: What drivers revolving around employees and processes can facilitate the organization to create more value for its customers? Conversely, what barriers block

Dr. Grace Tyng-Ruu Lin is currently Assistant Professor at the Faculty of Institute of Management of Technology of $\mathrm{Na}$ tional Chiao Tung University, Taiwan. She earned her PhD degree from Judge Institute of Management, University of Cambridge, in 2003. Prior to joining the MOT, NCTU. Lin was Assistant Professor (from 2004 to 2005) at the Department of Business Administration, National Chung Hsing University, Taiwan. Her research interests involve international marketing, strategic management, international economics, and technology innovation.

Mr. Jerry Lin is currently the sales director of Renishaw Company. Mr. Lin has worked in the measurement machinery industry over 20 years. He has his B.S. majoring in mechanical engineering from National Taiwan University of Science and Technology. He is now doing his part-time PhD in marketing field at National Central University, Taiwan. the organization from creating value for customers in examining the same dimensions? Does value creation direct an organization's profitability and competitiveness? Our questionnaire survey results show that the most recognized and agreed drivers of customer value creation in consideration of employees are "distinctive skills", "personal experience", "learning and training", and "team work"; and, in regard to the firm's processes, the key drivers are "innovation and evolution", "R\&D capability", and "capability for differentiation". Conversely, the most recognized and agreed barriers to customer value creation in relation to employees are a "distrustful environment" and "inadequate knowledge"; and, in terms of processes, they are "short of core technology", "poor resource support", and "bad services and attitudes". Furthermore, our in-depth interview outcomes reveal that "capital sufficiency" and "mergers and acquisitions" are in practice considered to be other important customer value creation drivers; in contrast, "cultural and structural barriers" and "short of mechanisms to measure customer value creation effectively" are viewed as additional critical barriers to customer value creation.

KEY WORDS: value creation, customer value creation, competitive advantage, drivers of customer value creation, barriers to customer value creation, machinery measuring equipment industry

\section{Introduction}

Taiwan represents one of the market leading countries in the machinery measuring equipment industry, alongside Germany, the United Kingdom, and Spain. The concept that the "product with highest price commands highest market share" is particularly evident with the global competitors in this field, including Heidenhain, Fagor, and Renishaw ${ }^{1}$, which currently covets the first, second and third largest market share worldwide, respectively. Fun- 
damental changes, however, are taking place in the global economy. Strategic and business practices are facing more competitive markets, more demanding shareholders, and customers who expect even higher levels of quality and value. High-tech machinery companies in Taiwan are therefore now striving to be a leading example in this changing marketplace. Given increased competitive pressures, many companies have been searching for approaches and strategies, which will enable more value creation and longer term sustainability.

We understand that the purpose of any business is to create value for customers, employees, and investors, and that the interests of these three groups are inextricably linked. Therefore, sustainable value cannot be created for one group unless it is created for all of them. The first focus should be on creating value for the customer, but this cannot be achieved unless the right employees are selected, developed, and rewarded, and unless investors receive consistently attractive returns (Batjargal, 2000).

What do we mean by value creation? For the customer, it entails making products and providing services that customers find consistently useful. In today's economy, such value creation is based typically on product and process innovation and on understanding unique customer needs with everincreasing speed and precision. But, companies can innovate and deliver outstanding service only if they tap the commitment, energy, and imagination of their employees. Value must therefore be created for those employees in order to motivate and enable them. Value for employees includes being treated respectfully and being involved in the decisionmaking process. Employees also value meaningful work, compensation incentives, and continued training and development. Creating value for investors means delivering consistently high returns on their capital. This generally requires both strong revenue growth and attractive profit margins. These, in turn, can be achieved only if a company delivers sustained value for its customers.

In view of the above, value creation plays a vital role in sustaining a company's competitive advantage. The motivation for this research lies chiefly in exploring the core issue of how businesses can create customer value toward becoming the market leaders and further compete successfully in the new economy. Drawing on data collected from three top- ranked global machinery measurement corporations (Heidenhain, Fagor, and Renishaw), this paper surveys and discusses the drivers of and barriers to enterprise value creation for customers and investors, across the dimensions of employees and process. To our knowledge, this scope of analysis has not been performed to date. This paper aims to answer several key questions: What drivers as assets can influence an organization to create value for customers in terms of employees and process? What barriers block an organization from creating value for customers in terms of employees and process? Will the progress of "value creation" direct an organization's profit and competition?

\section{Literature review}

Value creation and competition

MacDonald and Ryall (2001) provide a definition for value creation, competition, and value appropriation, and in their research they show that (1) there is a minimal level of value creation that is required if competition is to allow a firm to appropriate value; (2) there is a higher level of value creation guaranteeing that competition will result in value appropriation; (3) there is a measure of scarcity, which we call minimum value, with the feature that competition implies a firm surely appropriates value if and only if the firm's minimum value is positive; and (4) if an agent is to appropriate value, a particular structure of competition is required. In summary, a firm's ability to appropriate some or all of the value it creates is determined by the features of the value creation process somehow interacting with competition among firms (Saloner et al., 2001).

Value is relative to competition. Delivering a better trade-off between benefits and sacrifices in a product or service, i.e. offering better value than competition, will help a company to create sustainable competitive advantages (Eggert and Ulaga, 2002). Real value creation - and long-term growth and profitability - occurs when companies develop a continuous stream of products and services that offer unique and compelling benefits to a chosen set of customers. This means that to maintain industry leadership, a company must establish a sustainable process of value creation (Hill and Jones, 1998). 
What then becomes critical are the alternative responses to competition undertaken by different firms, some of which are more likely to succeed than others, given the nature of the business environment. In the emerging information economy, the most successful responses to competition focus on two areas: (1) innovation that drives down the cost of products and services while increasing their quality and variety, and (2) building a deeper understanding of changing customer needs within increasingly specific market segments. Responses that are rooted in a win/lose framework, such as taking a share from existing competitors in a zero-sum game, gaining power over customers (for example, by locking them into a proprietary computer operating system), or seeking to become the low-cost producer without simultaneously driving for world-class quality, are extremely dangerous (Slywotzky, 1996). Conversely, managers are more likely to stay focused on the higher return, win/win levers, if they aim not to beat the competition, per se, but to create more value than the competition - in other words, if they seek to achieve a "value-adding advantage". And by doing so, they are likely to be more successful than their competitors in the long run.

In order to gain this value-adding advantage or competitive advantage, Porter (1985) puts forward that "This advantage mainly depends on cost leadership, capability for differentiation, and focus". Besides, enterprises can be well developed if two major dominant strategies are properly integrated into business, and the noted strategies are "developing core competence" and "retrieving subtle strategic resources from outside world (so-called critical success factors, KSF)". The core competence of an organization may build up a product's competitive advantage on the market and creates a foundation for future product value (Quinn, 1999).

As a result, "value creation" can lead corporate competition to a fresh and more meaningful position. A company typically creates value for customers and superior returns for investors by producing goods or services that are better than their competitors by meeting a set of clearly defined needs for a specific set of customers. So, competition is a key variable in determining whether a product or service provides a differentiated benefit to the customer. However, the process of competition should never divert management from the primary task of creating those benefits by understanding and anticipating target customers' needs, excelling in product and process innovation, providing outstanding service, etc. (Davenport, 1992). Thus, we need to think of competition not as a goal, but as part of the business environment - a key element of the context in which a firm seeks to create value (Leonard-Barton, 1995).

\section{Other theories and perspectives of value creation}

Value creation is considered to be the key to collaborative supplier-employee-customer relationships. Customer-oriented management serves as a base for value creation. In the meanwhile, employees need to be motivated and trained to create customer value. The following discusses the essential literature collections concerning the above concerns.

The value proposition is the program of products, services, ideas, and solutions that a business marketer offers to advance the performance goals of the customer. The value proposition is an important organizing force in the company because it directs all employees to focus on the customer requirements, and it provides the means for the company to orient the minds of its customers towards its offerings (Kaplan and Norton, 1992). Besides this, capability is also important in the process of value creation. The required capability, for any well-run organization's value to its customers and the basis of its valuation by shareholders, is to expand its resources continuously and effectively match these resources with highpotential opportunities. This value-creation process is, in turn, built on the capabilities and motivation of the company's employees. Market-driven firms place high priority on customer-linking capabilities and closely align product decisions - as well as delivery, handling, service, and the value-chain activities - with the customer's operations (Brandenburger and Nalebuff, 1996).

Employees must be satisfied with both the product and services that are provided prior to supplying those items to the customer. Employees, of course, achieve themselves with what they are going to propose the value of product or service to customers. Value was then naturally created during the process of the exchange (Kotler, 2003). Besides, employees are functioning as a team to contribute their own knowledge, distinctive skills, specialties, and so on to 
the team to achieve the marketing values. Every team player has played evenly in the team with proper workloads; value is then naturally built up eventually (Kanigel, 1997).

Experience shows that in a value based management (VBM) culture, people are empowered to make better decisions, discipline their behavior, and work together more effectively as a team. Since each person contributes, risks and shares in each aspect of the work and ownership of the task, VBM helps to unite each employee's self interest around the company's bottom-line and corporate values. Poor value management detracts organizations from achieving successful business goals. In order to sustain the value in a business for the long term, a strategic decision-maker needs to point out clearly the direction to be taken and the struggles that could manifest themselves (Kelso and Adler, 1958).

Companies can transmit fundamental value perspectives and belief systems to its employees through a token, a ceremony, or a legend. Of course, companies must establish a working environment of mutual trust in order for employees to be expected to create value within the organization. A restrictive environment, which discourages individual initiative has been found to damage or even destroy the foundation of mutual links between the employees and the organization, which could even lead to a worse outcome of destroying the links to customers (Ouchi, 1981).

Furthermore, employees with limited knowledge tend to be disadvantaged in being able to create related benefits to customers. An inadequate knowledge base among its employees results in limited competencies for an organization, causing it to be ineffective in approaching the challenge of value creation (Lambert, 2004). Another factor limiting an organization's ability to provide value to customers is the arrogant and conceited attitudes, which may be present within the organization (Brandenburger and Nalebuff, 1996). Therefore, in order to avoid being replaced, a company must have the knowledge and capability to recognize the creation of business value, and this knowledge must be better than its rival's (Prahalad and Hamel, 1990). Distinctive skills may also be seen as equivalent to core competencies and refers to those skills and processes that are at the core of the company's value creating processes. Such skills differentiate one company from another in the same way that unique resources may also differentiate companies from each other. Distinctive skills are one factor that enables one company to out-perform another in the same market environment (Drucker, 2003).

Training is a learning process whereby people acquire capabilities to aid in the achievement of organizational goals. The ability to translate learning and training into job performance undoubtedly enhances competitiveness. Personal rewards or benefits must be relatively competitive and different, and should be based on performance to enhance the retention of employees (Mathis and Jackson, 2003). One key organizational value that affects employee retention is trust. One study of more than 600 employees found that trust and organizational values were noted as factors that most influenced the intentions by employees to stay with their current job. A distrustful environment could easily hurt the relationship between employee and employer thereby impacting the value creation chain within the organization. Hence, operational considerations such as strategies, policies, performance measures, rewards, analysis tools, and cultures are maximized in combination with VBM. If employees identify deviations between the above measures and their personal recognition for individual input, then value management has failed within the organization (Mathis and Jackson, 2003). In addition, perspective in the future maters the particular perceptions of effectiveness to the customer as well as expertise of company (Prahalad and Hamel, 1990). Overall, a positive value-creation culture in an organization determines the amount of value created for customers (Davenport and Short, 1990).

Combining all of the factors discussed above, customer feedback is still the most important benchmark that indicates the success or failure of a value creation program since a satisfied or unsatisfied customer will determine the long term sustainability of an organization. Customers require products that meet their needs and prompt services that must be perceived as better than the competitors. Customers' evaluation is based upon cost of product or service in effectively meeting their needs, prospective quality and performance, and innovation and evolution, which in summary forms the purchase experience for the product or service (Ghemawat, 2001). Bad service and attitude will result in unsatisfactory customer response that ultimately means no value was 
created during the encounter of the service activities (Fitzsimmons and Fitzsimons, 2004).

Business marketing strategy should therefore be based on the assessment of the company, competitor, and customer. A successful strategy focuses on identifying those opportunities in which the firm can deliver superior value to customers based on its distinctive competencies. From this perspective, marketing can be best understood as the process of defining, developing, and delivering value. By understanding customer needs, marketing managers can define value from the customer's perspective and convert that information into requirements for creating value within their organization. In turn, a firm's capabilities and skills determine the degree to which the company can meet these requirements and provide greater value than its competitors (Hamel, 1991).

\section{Research design and execution}

Value creation and its dynamics

Corporations sometimes choose not to focus on value creation and instead unintentionally make decisions that systematically decrease the long-term value of their businesses. It is perhaps because managers tend to define their organizations' interests narrowly. This narrow view is powerfully reinforced by financial accounting systems that are well adapted to the industrial economy, but are inadequate in the information economy. The accounting and finance conventions of the industrial age are effective at valuing tangible assets, but they largely ignore the value of harder-to-quantify assets like employee satisfaction, learning, R\&D effectiveness, customer loyalty, etc. (Mathis and Jackson, 2003). In the information age, intangible assets are far more important than the tangible assets that traditional accounting systems were designed to measure.

If management defines the organization's selfinterest (and consequently its goals) too narrowly for example, to maximize this year's or this quarter's reported earnings - it will view that interest as being at odds with the interests of customers and employees. Given that perspective, in the short term every dollar spent on employee training, for instance, is a dollar of lost profit. Every additional dollar earned from a customer, even if it comes at the cost of poor service or price gouging, improves this quarter's results (Kotler, 2003).

Alternatively, if managers define their company's interests broadly enough to include the interests of customers and employees, an equally powerful spiral of value creation can occur. Highly motivated, welltrained, properly rewarded employees deliver outstanding service, while effective R\&D investments lead to products that enjoy a significant value-adding advantage and generate higher margins. Satisfied, loyal customers (and new customers responding to word-of-mouth referrals) drive revenue growth and profitability for investors (Kotler, 2003).

One way to build an understanding of these dynamics is to identify the key capabilities, resources, and relationships that are the basic ingredients of value creation for a particular firm, and to think of those ingredients as assets that either grow or diminish over time, depending upon how they are managed. It is then useful to map a company's key assets by building a "value creation net" focused on employees, processes, customers, and investors (see Figure 1). In building the value creation net, managers should decide which assets are the most important drivers of the company's value-creation system. For example, employee learning and job satisfaction are two assets that could be tracked on the part of the employee in the value creation net.

As managers identify the strategic assets that belong in each value creation net, they also must articulate the relationships among those assets. By tracing the dynamics through which customer,

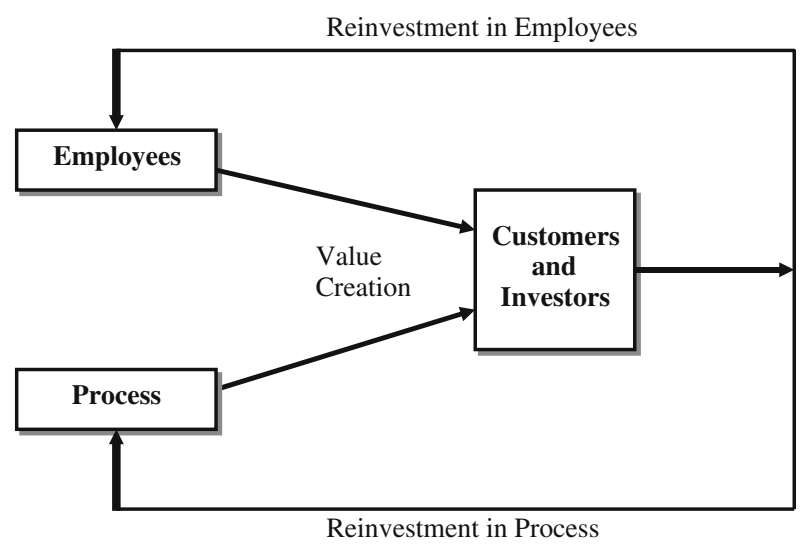

Figure 1. Value creation net. 
employee, and process assets accumulate, interact, and ultimately drive profitable growth, a company will be well on its way to managing the fundamentals of value creation and avoiding the pitfalls of management by following a set of narrow financial measures.

In Figure 1, the corporate value can be seen as being created from three major sources within the cycle, as noted above - from employees, from process, and from customers and investors through reinvestment. The target companies in our research are headquartered in Europe, which means that there are no shareholders located in Taiwan. Therefore, the value for investors can be considered in combination with the value for customers in this framework, which forms the basis for business growth and profitable returns. The profitable return is then significantly reinvested back into both the employees and process assets of the company, but the cycle could be either positive or negative, depending on the responses from the market.

\section{Research framework and method}

We have now established that both employees and process contribute significantly to enterprise value through a value creation course. The main objective

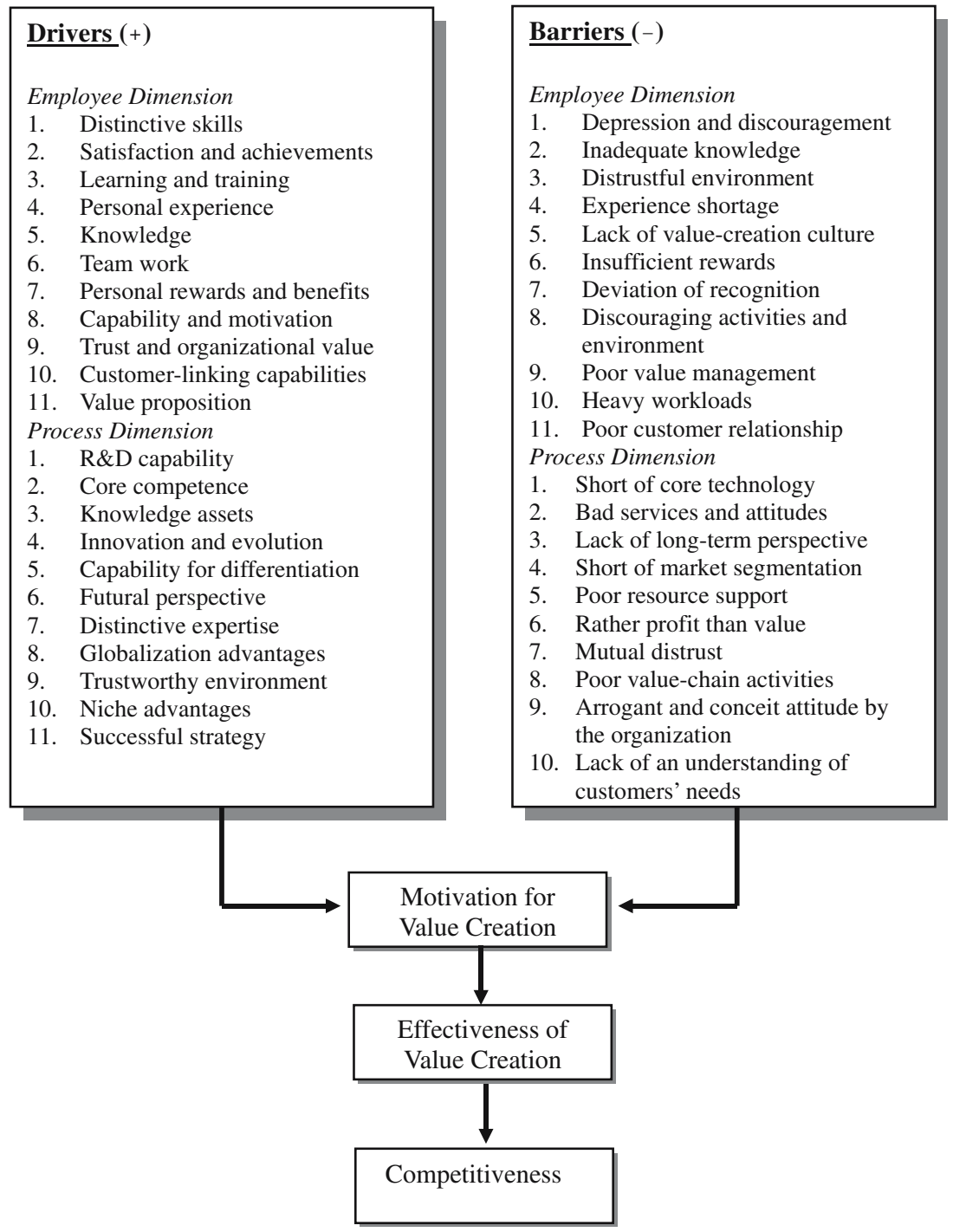

Figure 2. Factors of value creation. 
of this research, as noted before, is to explore the related subjects concerning the drivers of as well as barriers to customer value creation. Consequently, according to previous discussions on related literature, we conclude a preliminary assumption as to what the drivers of and barriers to customer value creation based on the dimensions of employee and processes should be, as shown in Figure 2. We will then adopt both a questionnaire survey and an in-depth interview as the principal research approaches to delve into the issues in question. Furthermore, from the above debates, we also learn that there is a positive interaction between enterprise value creation and business competitiveness. Therefore, in order to achieve competitive advantages, the firm must create more value than its competitors in the industry. Finally, this empirical study is designed to determine the importance relevance of these factors to customer value creation, leading to a useful reference for policy makers as to how companies can enhance the drivers for value creation and avoid or eliminate the barriers to the same end, thereby enhancing competitiveness more effectively.

\section{TABLE I}

Statistical table of factors of customer value creation on the employee dimension

\# $\quad$ TS AV SD $\quad$ Proposition

Drivers

A1 53

A2 49

A3 45

A4 47

A5 43

A6 44

A7 44

A8 40

A9 38

A10 43

A11 36

Ave. $43.82 \quad 3.67 \quad 0.79$

4.42 0.67 The employee creates value for customers because he possesses distinctive skills.

4.080 .79 The employee creates value for customers because he is satisfied and has achieved his objectives.

3.750 .62 The employee creates value for customers because of his learning and training.

3.920 .67 The employee creates value for customers because he has personal experience in the job.

3.751 .05 The employee creates value for customers because he has professional knowledge.

3.670 .65 The employee creates value for customers because he works as a teammate.

3.670 .89 The employee creates value for customers because he is offered by rewards and benefits.

3.330 .78 The employee creates value for customers because of his capability and motivation.

3.170 .94 The employee creates value for customers because of good trust and organizational values.

3.580 .67 The employee creates value for customers because of good customer-linking capabilities in the organization.

\section{Barriers}

B1 50

B2 45

B3 46

B4 48

B5 43

B6 44

B7 38

B8 35

B9 40

B10 35

B11 42

$\begin{array}{lll}4.17 & 0.83\end{array}$

$\begin{array}{lll}3.72 & 0.62\end{array}$

$\begin{array}{lll}3.83 & 0.58\end{array}$

$\begin{array}{lll}4.00 & 0.74\end{array}$

$\begin{array}{ll}3.58 & 0.79\end{array}$

79 The

$\begin{array}{lll}3.67 & 0.78\end{array}$

$\begin{array}{lll}3.17 & 0.58\end{array}$

lacks value-creation culture.

The employee creates
in the organization.

Ave. $\quad 42.36 \quad 3.53 \quad 0.72$ 


\section{Research targets}

Three world top-ranked machinery measuring equipment corporations are investigated: Heidenhain, Fagor, and Renishaw, which represent over $80 \%$ of the world market share in the machinery measuring equipment industry. Their business operations span from Europe and the United States to China, Japan and other Asian territories. We believe that these successful companies at the current stage have confronted both the drivers and barriers in their significant customer value creation processes, especially at the earlier stages of the corporation's development and operation. This paper therefore takes a broad framework of conducting an empirical survey and analysis targeting the above companies' leading subsidiaries in Taiwan ${ }^{2}$, giving rise to some implicational results.

In order to extend confidence in the research process, personnel are selected from a wide range of professionals within these companies. They are the management directors, $\mathrm{R} \& \mathrm{D}$ managers/engineers, sales managers/specialists, service managers/engineers, and IT personnel. The choice of these target employees for questioning is because value creation for a company's customers will be primarily undertaken by the middle to high levels of management (Nonaka and Takeuchi, 1995).

\section{Data analyses of questionnaire survey and in-depth interview}

\section{Questionnaire survey}

Through the investigation with a discrete period of time of almost 6 months, the data has been collected, arranged, and analyzed. We adopt both questionnaire survey and in-depth interview as the chief research methods to explore the issues in question. To the ready questions based on our preliminary assumption of what should be the drivers of as well as barriers to a corporation's customer value creation, the respondents answer in their own right with the designed questionnaire. In addition, the in-depth interviews are conducted in the meanwhile in order for more genuine and elaborated answers to be collected so that the questionnaire survey can be supplemented with the other meaningful analysis.
With the questionnaire survey, the Likert scale ${ }^{3}$, used the respondents can state the extent to which they agree with each of the questions. All the related outcomes are listed below. Tables I-IV are the statistical tables of factors of customer value creation with regard to the employee as well as process dimensions. The statistical items involve the sum, the average of the sum, the standard deviation, and the average of the standard deviation of the scores from the respondents' answers.

\section{Drivers of customer value creation}

From Tables I and II, we can see that in the field of the employee, "distinctive skills", "satisfaction and achievements", "personal experience", and "learning and training" rank 1st, 2nd, 3rd, and 4th, respectively, in terms of the total scores of drivers, which means that these four represent the main drivers of customer value creation in the employee area, according to our questionnaire. On the other hand, in the process aspect, "innovation and evolution", "R\&D capability", "knowledge assets", and "capability for differentiation" rank 1st, 2nd, 3rd, and 4th, respectively, in terms of the total scores of drivers, which means that these four denote the main drivers of customer value creation in the process field, according to our questionnaire. In other words, corporations are motivated to create value for their customers or investors mostly due to the factors above, with respect to the dimensions of employees and processes. Additionally, Tables III and IV show that some of the driver items have a higher total score than the average total score associated with lower standard deviation than the average standard deviation. That means that these driver items are the ones that are most accepted and agreed upon by the respondents. In terms of the employee, they are "distinctive skills", "personal experience", "learning and training", and "team work"; and in terms of process, they are "innovation and evolution", "R\&D capability", and "capability for differentiation".

\section{Barriers to customer value creation}

Likewise, concerning the employee, "depression and discouragement", "experience shortage", "distrustful environment", and "inadequate knowledge" rank 1st, 2nd, 3rd, and 4th, respectively, in terms of the total scores of barriers, which means that these four stand for the primary barriers to customer value 
creation in the employee area, according to our questionnaire survey. On the other hand, in terms of processes, "short of core technology", "arrogant and conceited attitude by the organization", "poor resource support", and "lack long-term perspective" rank 1 st, $2 \mathrm{nd}$, 3rd, and 4th, respectively, in view of the total scores of barriers, which means that these four account for the chief barriers to customer value creation in the process field, according to our questionnaire. In conclusion, corporations are hindered from creating value for their customers or investors due to the above factors, with regard to

\section{TABLE II}

Statistical table of factors of customer value creation on the process dimension

\begin{tabular}{|c|c|c|c|c|}
\hline \# & TS & AV & $\mathrm{SD}$ & Proposition \\
\hline \multicolumn{5}{|c|}{ Drivers } \\
\hline $\mathrm{C} 1$ & 53 & 4.42 & 0.67 & Your company creates value for customers because of the organization's $R E D$ capability. \\
\hline $\mathrm{C} 2$ & 46 & 3.83 & 0.72 & Your company creates value for customers because of the core competence. \\
\hline C3 & 49 & 4.08 & 0.90 & Your company creates value for customers because of knowledge assets. \\
\hline C4 & 56 & 4.67 & 0.49 & $\begin{array}{l}\text { Your company creates value for customers because of the } \\
\text { innovation and evolution of the organization. }\end{array}$ \\
\hline C5 & 47 & 3.92 & 0.67 & Your company creates value for customers because of the capability for differentiation. \\
\hline C6 & 43 & 3.58 & 0.51 & Your company creates value for customers because of the futural perspective of the organization. \\
\hline $\mathrm{C} 7$ & 38 & 3.17 & 0.58 & Your company creates value for customers because of distinctive expertise of the organization. \\
\hline $\mathrm{C} 8$ & 44 & 3.67 & 0.78 & $\begin{array}{l}\text { Your company creates value for customers because of } \\
\text { globalization advantages of the organization. }\end{array}$ \\
\hline C9 & 42 & 3.50 & 0.80 & Your company creates value for customers because of the trustworthy environment. \\
\hline C10 & 33 & 2.75 & 0.62 & Your company creates value for customers because of successful business strategies. \\
\hline C11 & 42 & 3.50 & 0.80 & Your company creates value for customers because of the niche advantages of the organization. \\
\hline Ave. & 44.82 & 3.74 & 0.69 & \\
\hline
\end{tabular}

\section{Barriers}

D1 $50 \quad 4.170 .83$ Your company does not create value for customers because the company is short of core technology.

D2 443.670 .65 Your company does not create value for customers because the company has bad services and attitudes.

D3 $45 \quad 3.750 .97$ Your company does not create value for customers because the company lacks long-term perspective.

D4 $39 \quad 3.250 .97$ Your company does not create value for customers because the company is short of market segmentation.

D5 $46 \quad 3.830 .83$ Your company does not create value for customers because of the poor resource supportfrom the organization.

D6 $39 \quad 3.250 .87$ Your company does not create value for customers because the company looks at profit rather than the values.

D7 $45 \quad 3.750 .97$ Your company does not create value for customers because the company is short of mutual trust within departments.

D8 $42 \quad 3.501 .00$ Your company does not create value for customers because of the poor value-chain activities of the organization.

D9 $47 \quad 3.921 .00$ Your company does not create value for customers because the whole organization's attitude is arrogant and conceited.

D10 $42 \quad 3.501 .00$ Your company does not create value for customers because the company lacks an understanding of customers' needs.

D11 $40 \quad 3.331 .07$ Your company does not create value for customers because of the poor system backup of the organization.

Ave. $43.55 \quad 3.63 \quad 0.92$ 
TABLE III

Leading drivers of and barriers to customer value creation on the employee dimension

\begin{tabular}{|c|c|c|c|}
\hline$\#$ & TS & SD & Item \\
\hline \multicolumn{4}{|l|}{ Drivers } \\
\hline A1 & 53 & 0.67 & Distinctive skills \\
\hline A4 & 47 & 0.67 & Personal experience \\
\hline A3 & 45 & 0.62 & Learning and training \\
\hline A6 & 44 & 0.65 & Team work \\
\hline Total average & 43.82 & & \\
\hline Total average & & 0.79 & \\
\hline \multicolumn{4}{|l|}{ Barriers } \\
\hline B3 & 46 & 0.58 & Distrustful environment \\
\hline $\mathrm{B} 2$ & 45 & 0.62 & Inadequate knowledge \\
\hline Total average & 42.36 & & \\
\hline Total average & & 0.72 & \\
\hline
\end{tabular}

employee and processes. Furthermore, Tables III and IV also show that some of the barrier subjects have a higher total score than the average total score, along with a lower standard deviation than the average standard deviation. This means that these barrier items are best accepted and agreed upon by the respondents. On the part of the employee, they are "distrustful environment" and "inadequate knowledge"; in the field of processes, they are "short of core technology", "poor resource support", and "bad services and attitudes".

\section{TABLE IV}

Leading drivers of and barriers to customer value creation on the process dimension

\begin{tabular}{|c|c|c|c|}
\hline \# & TS & $\mathrm{SD}$ & Item \\
\hline \multicolumn{4}{|l|}{ Drivers } \\
\hline $\mathrm{C} 4$ & 56 & 0.49 & Innovation and evolution \\
\hline C1 & 53 & 0.67 & R\&D capability \\
\hline C5 & 47 & 0.67 & Capability for differentiation \\
\hline Total average & 44.81 & & \\
\hline Total average & & 0.69 & \\
\hline \multicolumn{4}{|l|}{ Barriers } \\
\hline D1 & 50 & 0.83 & Short of core technology \\
\hline D5 & 46 & 0.83 & Poor resource support \\
\hline D2 & 44 & 0.65 & Bad services and attitudes \\
\hline Total average & 43.55 & & \\
\hline Total average & & 0.92 & \\
\hline
\end{tabular}

\section{In-depth interview}

The field interview or in-depth interview is a joint product of a researcher and a member, involving asking questions, listening, expressing interest, and recording what was said (Mishler, 1986). Therefore, its purpose is to offer a more comprehensive fact report and to help build an insightful understanding of the target issues during different research processes. Most of the interview respondents agree to the proposition of questions with the previous questionnaire. That means the preliminary assumptions as to what the drivers of and barriers to customer value creation are have been most of the part confirmed through our empirical research. The in-depth interview here then also offers it with supplementary viewpoints regarding the related issues under consideration. The following is concerned with the main outcome of our in-depth interview.

1. "Being a market leader, how do you view the role of value creation at the corporate strategy level?" Most of the interviewers/respondents say that the "value creation" indeed plays a very important role in the company's business strategy. Other significant standpoints include:

"There are several critical factors that lead to our success in this industry. But the first goal that we have is to create value for investors. If not, we have no right to be there. We should either make way for someone else to step on or the board should ask us to leave."

"If you're competing on price, you'll never achieve maximum profitability. Instead, everyone's job has become value creation. But are you sure that you're providing value to your customers?"

"What is my organization's strategy? How does this strategy create real financial value? What role do I play in the value-creation process? These are the questions every CFO should be asking. In order to leverage that financial discipline, the CEO needs a strong understanding of how a particular strategy and its value drivers contribute to true value creation."

"Based on my experience, more than half of all companies feel that they aren't getting true value from their suppliers.", and "Companies cannot always hope to create products (value) and ex- 
change value as they have done, but instead have to co-create value at the point of exchange with customers. We call this co-creation of value."

2. "Could you briefly talk about your opinions of value creation itself and the relationship between value creation and business competitiveness?" Most of the participants agree that value creation is positively correlated to organizational competitiveness: The more the value is created by employees and processes in the company, the greater the competitiveness can be achieved. Other answers include:

"Ideas can often be produced throughout the brainstorming process within the employee group; so, employees should be valued as significant assets for the company for all concerned."

"The activity of value creation does not only lead to customer satisfaction but also the overall growth of the employees as well as the company."

3. "Apart from the drivers of value creation proposed in the questionnaire, according to your experiences, what else (in the aspects of employee and process) are also the key motivation factors of customer value creation?" Major feedbacks include:

"Successful value creators never suer from a capital shortage. They can either generate sucient capital internally to meet their investment needs, or attract the capital they need from the markets, which never stop looking for profitable investment opportunities."

"Outstanding performance with high profitability will drive value creation.",

"According to my company's experiences, buyers and sellers can create a lot of value through mergers and acquisitions (M\&A), because both can and should benefit from each other."

4. "Apart from the barriers to value creation proposed in the questionnaire, according to your experiences, what else (in the aspects of employee and process) are also the key barriers to customer value creation?"' Two major comments include:

"Sometimes the cultural and structural barriers to value creation are the most dicult things for the managers to handle."

"Companies usually have no mechanisms to eectively measure customer value creation. What we need to have is an analytical tool that not only analyzes a company's products and services, but also compares and contrasts them to products and services of competitors. Besides, the concept of value must measure customer satisfaction not only with regard to the service itself, but also with regard to the price paid for it."

\section{Concluding remarks}

There is a long-standing discussion on the positive interactions between enterprise value creation and business competitiveness. The corporate value can be seen as being created from three major sources within the cycle - from employees, from processes, and from customers or investors through reinvestment. To achieve competitive advantages, a firm must create more value than its competitors in the industry. Emphasizing that, firms should explore the positive drivers of customer value creation, allowing for a true value creation that will lead to increased competitiveness. On the other hand, in reality, there are barriers that hinder customer value creation. Targeting the above issues, we collect relevant literature at the first stage; based on these preliminary theoretical assumptions, this paper then conducts an empirical study by surveying and analyzing the relevance given by the investigated firms regarding the concerns as drivers of and barriers to customer value creation. The following concludes the research results:

1. Through our data analysis, some customer value creation drivers are most recognized and agreed upon by the respondents to the questionnaire, and they are "distinctive skills", "personal experience", "learning and training", and "team work" with regard to the employee. In the field of processes, they are "innovation and evolution", "R\&D capability", and "capability for differentiation".

2. Through our data analysis, some customer value creation barriers are most recognized and agreed upon by the respondents to the questionnaire, and they are a "distrustful environment" and "inadequate knowledge" on the part of employee. In the field of processes, they are "short of core technology", "poor resource support", and "bad services and attitudes".

3. Most of the interview respondents agree to the proposition of questions with the previous questionnaire. The other in-depth interview conducted by this research then offers supplementary viewpoints regarding the related issues under consideration. The fact that value creation plays a critical role in promoting 
competitiveness, which leads to market leadership, has been ordinarily recognized. Other more remarkable feedbacks note that apart from the assumed factors of customer value creation, "capital sufficiency" and "merger and acquisition" are in practice considered to be other important drivers, and in contrast, "cultural and structural barriers" and "short of mechanism to effectively measure customer value creation" are viewed as other critical barriers in the target subject.

As noted before, competition among firms is actually a process of bidding for the dollar votes of consumers as well as investors. This paper suggests that the drivers of and barriers to customer value creation that have been explored and analyzed should be examined carefully by the top managers, so that the related enterprise policies can be facilitated to be set and implemented, promoting competitive advantages for the company as a whole. That is, inorder to achieve competitive advantages, the firm should be able to create more value than its competitors in the industry. This research has contributed at the first stage by drawing upon an empirical example to determine the importance relevance of these factors to customer value creation, so the policy makers can further know how to lead the company to boost the drivers for value creation and avoid or eliminate the barriers to the same end, thereby enhancing competitiveness more effectively.

\section{Notes}

1 HEIDENHAIN, FAGOR, and RENISHAW are three global machinery measurement companies, which are headquartered in Germany, Spain, and the United Kingdom, respectively.

2 For these three world top-ranked corporations, Taiwan plays a very important role. In Asia, the subsidiary located in Taiwan is the largest one for Fagor and Renishaw, and the second largest for Heidenhain, in terms of the operational volume and market share.

3 The Likert scale is designed to examine how strongly subjects agree or disagree with statements on a 5point scale: Strongly disagree (1); Disagree (2); Neither agree nor disagree (3); agree (4); Strongly agree (5).

\section{References}

Batjargal, B.: 2000, 'The Dynamics of Entrepreneurial Networks in a Transitional Economy', Working Paper, No. 350 (William Davidson Institute, Ann Arbor, USA).

Brandenburger, M. A. and J. Nalebuff: 1996, Co-opetition (Currency Doubleday Publication, New York).

Davenport, H. T.: 1992, Process Innovation: Reengineering Work through Information Technology (Harvard Business School Press, Boston).

Davenport, H. T. and J. E. Short: 1990, 'The New Industrial Engineering: Information Technology and Business Process Redesign', Sloan Management Review 31, 11-27.

Drucker, F.P.: 2003, Managing in the Next Society (St. Martin's Pressing).

Eggert, A. and W. Ulaga: 2002, 'Customer-Perceived Value: A Substitute for Satisfaction in Business Markets?', Journal of Business and Industrial Marketing 17(2-3), 107-118.

Fitzsimmons, A. J. and J. M. Fitzsimmons: 2004, Service Management (McGraw-Hill).

Ghemawat, P.: 2001, Strategy and Business Landscape: Core Concept (Prentice Hall).

Hamel, G.: 1991, 'Competition for and Inter-partner Learning within International Strategic Alliances', Strategic Management Journal 12, 83-103.

Hill, C. and G. R. Jones: 1998, Strategy Management Theory: Integrated Approach, McGraw-Hill.

Kanigel, R.: 1997, The One Best Way (Viking Penguin).

Kaplan, S. R. and P. D. Norton: 1992, 'The Balanced Scorecard: Measures that Drive Performance', Harvard Business Review 70, 71-79.

Kelso, O. L. and J. M. Adler: 1958, The Capitalist Manifesto (Random House).

Kotler, P.: 2003, Marketing Insights from $A$ to $Z$ (John Wiley and Sons, New York).

Lambert, S.: 2004, 'ACT Budget 2004-05 Community Briefing Report' (Department of Treasury, Australian Capital Territory Government, mimeo).

Leonard-Barton, D.: 1995, Wellsprings of Knowledge: Building and Sustaining the Sources of Innovation (Harvard Business School Press, Boston).

MacDonald, G. and M. D. Ryall: 2001, 'Lower Bounds on Equilibrium Payoffs in Superadditive Value Games', Research Working Paper (University of Rochester).

Mathis, L. R. and H. J. Jackson: 2003, Human Resource Management (Thomson Publishing).

Mishler, E. G.: 1986, Research Interviewing: Context and Narrative (Harvard University Press, Cambridge). 
Nonaka, I. and H. Takeuchi: 1995, The Knowledge-Creating Company: How Japanese Companies Create the Dynamics of Innovation (Oxford University Press, New York).

Ouchi, G. W.: 1981, Theory Z (Addison Wesley, MA).

Porter, M. E. 1985, Competitive Advantage: Creating and Sustaining Superior Performance (Free Press).

Prahalad, C. K. and G. Hamel: 1990, 'The Core Competence of the Corporation', Harvard Business Review 68, 79-91.

Quinn, J. B.: 1999, 'Strategic Outsourcing: Leveraging Knowledge Capabilities', Sloan Management Review 40, 9-22.

Saloner, G., A. Shepard and J. Podolny: 2001, Strategic Management (John Wiley \& Sons, New York).
Slywotzky, J. A.: 1996, Value Migration: How to Think Several Moves Ahead of the Competition (Harvard Business School Press, Boston).

Grace Tyng-Ruu Lin Institute of Management of Technology, National Chiao Tung University, Hsinchu,

Taiwan E-mail:gtrl@faculty.nctu.edu.tw

Jerry Lin

EMBA, Department of Business Administration, National Chung Hsing University, Taichung, Taiwan 